\title{
11. SHIPBOARD GEOCHEMICAL ANALYSIS, LEG 7, GLOMAR CHALLENGER
}

\author{
E. L. Gealy and Richard Dubois, Scripps Institution of Oceanography, La Jolla, California
}

Sediments collected on Leg 7 were sampled for geochemical analysis at sea. Some samples were analyzed for $p \mathrm{H}$, Eh and salinity at sea; the remainder were delivered to shore-based laboratories for further work. This report summarizes the sampling and handling procedures used at sea and presents the results of the shipboard analyses. Handling procedures used were still in the development stage, and results should be used with caution. Results of shore-based geochemical analyses are presented elsewhere in this report.

\section{SAMPLING PROCEDURES}

Generally, samples for geochemical analysis were taken after the core had been split, and most sections were split after they had been standing at room temperature for many ( 8 or more) hours. Sections $1,3,4$ and 5 of most cores taken from Hole 62.1 were stored at $4^{\circ} \mathrm{C}$ many days before they were processed. In a few cases, prior to splitting the core, the core liner was drilled and a needle inserted. A sample of interstitial gases were obtained in one or more vacuum containers. The containers were sealed and stored under refrigeration. As soon as possible after the sections were split, generally within 5 minutes, three or four 25 to 30 -cubic centimeter samples for major elements, carbon dioxide, $\mathrm{C}$-isotope and shipboard analyses were collected at 20 meter intervals at each site. One sample was stored, unsqueezed, for shore analysis. The remainder were squeezed as soon after sampling as possible. Four 25 to 30-cubic centimeter additional samples were collected for carbon dioxide and $\mathrm{C}$-isotope analysis. All samples were sealed in glass bottles with polyseal caps and stored under refrigeration. Two samples (and, where carbon dioxide and $\mathrm{C}$-isotope samples were collected, three samples) of 25 to 30 cubic centimeters of sediment were combined and squeezed to provide interstitial solutions (about 5 cubic centimeters) for analysis for major dissolved chemical species $\left[\mathrm{O}^{18} / \mathrm{O}^{16}\right.$, H/D] and shipboard analysis (about 2.5 cubic centimeters). The squeezed solutions and residue were stored at $4^{\circ} \mathrm{C}$.

Four samples of 800 to 1000 grams of sediment were collected for trace element analysis (in concentrations of ppb). One-half of the working half over a 60 to 80 centimeter interval was removed, cleaned and placed in saran-coated mylar bags. Care was used to avoid contamination by hands, plastics or organic materials. After squeezing, the sediment residue was returned to the original mylar bag, the air was evacuated from the bag, and the sediment frozen at $-20^{\circ} \mathrm{C} \pm$. The solutions were refrigerated at $4^{\circ} \mathrm{C} \pm$.

\section{ANALYTICAL METHODS}

Shipboard analyses of interstitial water samples were confined to measurements of $p \mathrm{H}$, Eh and salinity. Salinities were measured using the Goldberg refractometer. Measurements of $p \mathrm{H}$ and $\mathrm{Eh}$ were made by electrochemical methods. The methodology is set forth in detail in the Shipboard Manual of the Deep Sea Drilling Project (revised July, 1968). Results of shipboard geochemical analyses are given in Table 1 , and are summarized below.

\section{RESULTS}

\section{Site 61}

Because of severe disturbance of the sediments during the coring operations, only one interstitial water sample was taken from this site. This one, from Section 2 of Core 1 of Hole 61.1, had a salinity of 34.7 per mille, $p \mathrm{H}$ of 7.53 , and $\mathrm{Eh}$ of -300 millivolts.

\section{Site 62}

The salinity readings at Holes 62.0 and 62.1 are all in the range 34.1 to 34.7 per mille. This is the salinity of local sea water \pm 0.3 per mille so that, given the error inherent in the instrument, no conclusions can be made except to say that the salinity of the interstitial water is similar to that of present-day sea water.

The $p \mathrm{H}$ and Eh readings for Hole 62.0 vary regularly with depth, and all the $p \mathrm{H}$ readings are less alkaline than that of local sea water $(p \mathrm{H} \mathrm{8.4)}$. The readings begin at 100 meters where the $p \mathrm{H}$ and $\mathrm{Eh}$ are 7.69 and -260 millivolts, respectively, then drop to 6.92 and -500 millivolts at 300 meters, only to rise again to 7.52 and -372 millivolts at 500 meters. Unfortunately, the results from Hole 62.1 which parallels Hole 62.0 are not as readily interpreted, and, in fact, are in conflict with those obtained from Hole 62.0. Data from Hole 62.1 consist of fifteen sets of values taken at approximately 40 meter intervals from 0 to 340 meters. The $p \mathrm{H}$ and Eh values are 7.38 and -310 millivolts, respectively, in the uppermost core and change irregularly with depth to values of 8.1 and +1.38 millivolts at 340 meters. Thus, at 300 meters, the values for $p \mathrm{H}$ and $\mathrm{Eh}$ in Hole 62.0 are 6.92 and -500 millivolts, respectively, 
but the values in Hole 62.1 are 7.71 and +120 millivolts. Since these should come from approximately the same stratigraphic horizon, this is a serious conflict. The reason for this difference can probably be found in the fact that pore water left standing with the $p \mathrm{H}$ and Eh electrodes in it becomes progressively more basic with time, whereas the Eh becomes progressively more positive. While drilling Hole 62.0, the cutting and processing operation kept up with the drilling operation fairly well, so that the cores were split within 8 to 12 hours after coming on deck, but while drilling Hole 62.1 , the cutting operation fell progressively behind. As a result, the values for the top of Hole 62.1 are in much closer agreement with the values from the corresponding horizons in Hole 62.0 than are the values from deeper levels in the two holes.

\section{Site 63}

The salinity determinations at Site 63 were all at or near that of local sea water, that is, 34.4 per mille. The salinity varies irregularly with depth, and the total variation over the hole is only \pm 0.3 per mille, which is close to the limit of resolution of the instrument.

The $p \mathrm{H}$ values are all more acidic than local sea water (that is, 8.3 to 8.4 ), ranging from 7.22 to 7.57 , the average being 7.39 . There is an irregular trend toward greater acidity with greater depth.

The Eh readings show values of about +150 millivolts in the first 60 meters of sediment. In the interval 100 to 270 meters, the values are (with one exception) around -325 millivolts.

\section{Site 64}

The interstitial water data for Site 64 consist of six sets of values for $\mathrm{Eh}, p \mathrm{H}$ and salinity, from 0 to 460 meters. The material recovered from the hole below 460 meters was unsuitable for interstitial water sampling because it consisted of hard chalk. The salinity readings are all the same as local sea water (34.1 per mille), except for the value at 460 meters, which is 35.0 .

The $p \mathrm{H}$ values show that the sediments become more acid as the depth increases. The $p \mathrm{H}$ values at the surface of the sediment have a $p \mathrm{H}$ of 7.82 and decrease, with one slight irregularity, to 7.23 at 460 meters. The $p \mathrm{H}$ of local surface sea water is 8.30 .

The Eh readings showed with a value of -320 millivolts at the surface, and of +116 millivolts at 100 meters. From 100 meters to 460 meters, the Eh values become regularly more negative with depth, and the value of -330 millivolts at 460 meters is almost the same as the surface value.

\section{Site 65}

The interstitial water data for Site 65 consist of seven sets of values for $\mathrm{Eh}, p \mathrm{H}$ and salinity. These values are spaced evenly over the interval 20 to 150 meters. The salinity measurements are all the same as local sea water (34.4 per mille \pm 0.3 per mille), except for the first sample, which had a salinity of 35.2 per mille.

The two $p \mathrm{H}$ values above 60 meters were 7.51 and 7.53 , while the five samples below 60 meters had $p \mathrm{H}$ values of $7.69 \pm 0.01$, except for one value which was 7.63. The $p \mathrm{H}$ of local sea water was 8.34 .

The Eh was negative for all samples taken at Site 65. The values start at -242 millivolts, then irregularly become more negative to a depth of 125 meters, where the value is -513 millivolts. Below 125 meters, the values are about -325 millivolts.

\section{Site 66}

The $p \mathrm{H}$ values ranged from 7.53 to 7.79 , the higher value being from the pelagic clay section. All values are lower than local sea water ( 8.3 to 8.4). No vertical pattern is apparent.

The Eh values were negative for the radiolarian ooze and volcanic mud. The pelagic clay Eh was positive $(+194)$.

Salinity measurements showed little deviation from local sea water ( 34.4 to 34.6 per mille), with one exception (35.2 per mille). No vertical pattern is evident.

\section{Site 67}

Because of severe disturbance of the sediments during the coring operation, no interstitial water samples were taken. 
TABLE 1

Interstitial Water Analysis: Shipboard

\begin{tabular}{|c|c|c|c|c|c|c|c|c|c|}
\hline Hole & Core & Section & $\begin{array}{l}\text { Interval From } \\
\text { Top }(\mathrm{cm})\end{array}$ & $p \mathrm{H}$ & Eh & $\underset{{ }^{\circ} \mathrm{C}}{\mathrm{Temp}}$ & $\Delta \mathrm{N}$ & Salinity & Comments \\
\hline 61.1 & 1 & 2 & $66-76$ & 7.53 & -300 & 24 & 63 & 34.7 & $\begin{array}{l}\text { A deep hard core showing little evidence of disturbance } \\
\text { or drilling fluid intrusion. }\end{array}$ \\
\hline 62.0 & 1 & 2 & $89-100$ & 7.69 & -260 & 24 & 63 & 34.7 & $\begin{array}{l}\text { Core is a nannofossil-chalk ooze. It is stiff but disturbed, } \\
\text { showing little signs of drilling fluid intrusion. }\end{array}$ \\
\hline 62.0 & 2 & 2 & $36-47$ & 7.48 & -350 & 23 & 63 & 34.7 & $\begin{array}{l}\text { From a nannofossil-chalk ooze, showing little signs of } \\
\text { drilling fluid intrusion and disturbance. }\end{array}$ \\
\hline 62.0 & 3 & 2 & $90-100$ & 6.92 & -500 & 23 & 62 & 34.1 & $\begin{array}{l}\text { From a very hard dry undisturbed nannofossil-chalk } \\
\text { ooze. }\end{array}$ \\
\hline 62.0 & 3 & 3 & $69-140$ & & & & & & $\begin{array}{l}\text { From a relatively undisturbed hard dry nannofossil-chalk } \\
\text { ooze that showed little sign of drilling fluid intrusion. }\end{array}$ \\
\hline 62.0 & 4 & 4 & $30-40$ & 7.50 & -346 & 24 & 62 & 34.1 & $\begin{array}{l}\text { From a nannofossil-chalk ooze that is hard and dry and } \\
\text { relatively undisturbed, with little drilling fluid intrusion. }\end{array}$ \\
\hline 62.0 & 5 & 3 & $30-40$ & 7.52 & -372 & 23 & 62 & 34.1 & $\begin{array}{l}\text { From a very hard dry undisturbed nannofossil-chalk } \\
\text { ooze. Drilling fluid intrusion unlikely. }\end{array}$ \\
\hline 62.1 & 1 & 3 & $30-41$ & 7.38 & -310 & 24 & 62 & 34.1 & $\begin{array}{l}\text { From an undisturbed soft nannofossil-chalk ooze show- } \\
\text { ing no sign of drilling fluid intrusion. }\end{array}$ \\
\hline 62.1 & 2 & 4 & $40-50$ & 7.35 & -426 & 24 & 62 & 34.1 & $\begin{array}{l}\text { From an undisturbed soft nannofossil-chalk ooze that } \\
\text { shows no sign of drilling fluid intrusion. }\end{array}$ \\
\hline 62.1 & 4 & 6 & $39-48$ & 7.63 & +145 & 23 & 62 & 34.1 & $\begin{array}{l}\text { From a soft but relatively undisturbed nannofossil-chalk } \\
\text { ooze. Sampling was delayed four days due to operational } \\
\text { necessities. }\end{array}$ \\
\hline 62.1 & 6 & 5 & $30-38$ & 7.27 & -356 & 25 & 62 & 34.1 & $\begin{array}{l}\text { From a soft, very disturbed nannofossil-chalk ooze that } \\
\text { has possibly suffered drilling fluid intrusion. }\end{array}$ \\
\hline 62.1 & 8 & 5 & $40-51$ & 7.24 & -586 & 24 & 62 & 34.1 & $\begin{array}{l}\text { From a soft but not mushy nannofossil-chalk ooze. The } \\
\text { core was not too disturbed, but drilling fluid intrusion is } \\
\text { a possibility. }\end{array}$ \\
\hline 62.1 & 12 & 2 & & & & & & & $\begin{array}{l}\text { From a disturbed nannofossil-chalk ooze that possibly } \\
\text { had drilling fluid intrusion. }\end{array}$ \\
\hline 62.1 & 14 & 5 & $73-80$ & 7.46 & +146 & 24 & 63 & 34.7 & $\begin{array}{l}\text { From a mushy disturbed nannofossil-chalk ooze that } \\
\text { probably has drilling fluid in it. The core had hard and } \\
\text { soft sections. The sample was mostly from a hard section. }\end{array}$ \\
\hline
\end{tabular}


TABLE 1 - Continued

\begin{tabular}{|c|c|c|c|c|c|c|c|c|c|}
\hline Hole & Core & Section & $\begin{array}{l}\text { Interval From } \\
\text { Top }(\mathrm{cm})\end{array}$ & $p \mathrm{H}$ & Eh & $\underset{{ }^{\circ} \mathrm{C}}{\mathrm{Temp}}$ & $\Delta \mathrm{N}$ & Salinity & Comments \\
\hline 62.1 & 16 & 5 & $49-59$ & 7.26 & +165 & 24 & 62.5 & 34.4 & $\begin{array}{l}\text { From a firm undisturbed nannofossil-chalk ooze that is } \\
\text { unlikely to have drilling fluid in it. }\end{array}$ \\
\hline 62.1 & 18 & 2 & $40-50$ & 7.56 & +159 & 24 & 63 & 34.7 & $\begin{array}{l}\text { From a moderately disturbed, firm, relatively dry } \\
\text { nannofossil-chalk ooze drilling fluid intrusion is unlikely. }\end{array}$ \\
\hline 62.1 & 20 & 5 & $40-47$ & 7.43 & +150 & 24 & 63 & 34.7 & $\begin{array}{l}\text { From a disturbed but firm nannofossil-chalk ooze. } \\
\text { Drilling fluid intrusion unlikely. }\end{array}$ \\
\hline 62.1 & 24 & 5 & $40-48$ & 7.51 & -185 & 24 & 62 & 34.1 & $\begin{array}{l}\text { From a moderately disturbed nannofossil-chalk ooze } \\
\text { that had alternating hard and soft sections. Sample } \\
\text { mostly from a hard section. }\end{array}$ \\
\hline 62.1 & 26 & 2 & $132-140$ & 7.49 & +130 & 24 & 63 & 34.7 & $\begin{array}{l}\text { From a moderately disturbed nannofossil-chalk ooze. } \\
\text { Sample taken in a hard section. }\end{array}$ \\
\hline 62.1 & 28 & 5 & $39-50$ & 7.41 & +89 & 24 & 63 & 34.7 & $\begin{array}{l}\text { From a hard nannofossil-chalk ooze that had alternating } \\
\text { hard and soft layers. This may indicate drilling fluid } \\
\text { intrusion. }\end{array}$ \\
\hline 62.1 & 30 & 2 & $40-50$ & 7.47 & +102 & 24 & 63 & 34.7 & $\begin{array}{l}\text { From a hard nannofossil-chalk ooze. Probably has little } \\
\text { drilling fluid intrusion. }\end{array}$ \\
\hline 62.1 & 34 & 5 & $40-50$ & 7.96 & +139 & 2 & 63 & 34.7 & From a hard dry undisturbed nannofossil-chalk ooze. \\
\hline 62.1 & 36 & 2 & $122-132$ & 8.10 & +138 & 23 & 62.5 & 34.3 & $\begin{array}{l}\text { From a hard dry nannofossil-chalk ooze. There is some } \\
\text { chance of drilling fluid intrusion, but the sampled inter- } \\
\text { val was pretty compact. }\end{array}$ \\
\hline 63.0 & 1 & 5 & $40-50$ & 7.57 & +147 & 25 & 62 & 34.1 & $\begin{array}{l}\text { From a soft pelagic clay which may have drilling fluid } \\
\text { in it. }\end{array}$ \\
\hline 63.0 & 2 & 3 & $40-50$ & 7.41 & +163 & 24 & 62.5 & 34.4 & $\begin{array}{l}\text { From a firm nannofossil-chalk ooze that shows no sign } \\
\text { of drilling fluid intrusion. }\end{array}$ \\
\hline 63.0 & 3 & 2 & $80-91$ & 7.28 & -242 & 23 & 63 & 34.7 & $\begin{array}{l}\text { From a very firm nannofossil-chalk ooze that shows no } \\
\text { sign of drilling fluid intrusion. }\end{array}$ \\
\hline 63.0 & 4 & 2 & $80-90$ & 7.41 & -457 & & 62.5 & 34.4 & $\begin{array}{l}\text { From a hard dry nannofossil-chalk ooze that is unlikely } \\
\text { to contain drilling fluid. }\end{array}$ \\
\hline 63.1 & 5 & 2 & $60-70$ & 7.34 & -332 & 24 & 62.5 & 34.4 & From a hard but disturbed nannofossil-chalk ooze. \\
\hline 63.1 & 7 & 2 & $79-90$ & 7.22 & -336 & 23 & 63 & 34.7 & $\begin{array}{l}\text { From a firm light-brown chalk ooze that was only } \\
\text { slightly disturbed. No signs of drilling fluid intrusion. }\end{array}$ \\
\hline
\end{tabular}


TABLE 1 - Continued

\begin{tabular}{|c|c|c|c|c|c|c|c|c|c|}
\hline Hole & Core & Section & $\begin{array}{l}\text { Interval From } \\
\text { Top }(\mathrm{cm})\end{array}$ & $p \mathrm{H}$ & Eh & $\underset{{ }^{\circ} \mathrm{C}}{\mathrm{Temp}}$ & $\Delta \mathrm{N}$ & Salinity & Comments \\
\hline 63.1 & 7 & 3 & $80-150$ & & & & & & $\begin{array}{l}\text { From a light-brown chalk ooze that was only slightly } \\
\text { disturbed. The sample was quite firm, so there is little } \\
\text { chance of drilling fluid intrustion. }\end{array}$ \\
\hline 63.1 & 9 & 2 & $82-90$ & 7.27 & -350 & 24 & 62.5 & 34.4 & $\begin{array}{l}\text { From a hard brown chalk ooze. Sample was from hard } \\
\text { undisturbed section, so is unlikely to have drilling fluid } \\
\text { in it. }\end{array}$ \\
\hline 63.1 & 11 & 5 & $39-44$ & 7.47 & -305 & 24 & 62 & 34.1 & $\begin{array}{l}\text { From a chalk ooze that had hard chunks and soft greatly } \\
\text { disturbed sediments. The sample was entirely from one } \\
\text { of the hard chunks. }\end{array}$ \\
\hline 63.1 & 13 & 3 & $32-35$ & 7.36 & +172 & 25 & 62 & 34.1 & $\begin{array}{l}\text { From a chalk ooze that had hard chunks and soft, greatly } \\
\text { disturbed sediments. The sample was entirely from one } \\
\text { of the hard chunks. }\end{array}$ \\
\hline 63.2 & 2 & 3 & $30-38$ & 7.58 & +132 & 24 & 62.5 & 34.4 & $\begin{array}{l}\text { From a soft disturbed greenish marl ooze that may have } \\
\text { drilling fluid in it. }\end{array}$ \\
\hline 64.0 & 1 & 3 & $119-127$ & 7.82 & -320 & 24 & 62 & 34.1 & $\begin{array}{l}\text { From a relatively undisturbed but very soft nannofossil- } \\
\text { chalk ooze. }\end{array}$ \\
\hline 64.0 & 2 & 2 & $108-119$ & 7.72 & +116 & 25 & 62 & 34.1 & $\begin{array}{l}\text { Little or no drilling fluid intrusion. Little disturbance of } \\
\text { a foraminiferal-nannofossil chalk ooze. }\end{array}$ \\
\hline 64.0 & 3 & 4 & $80-90$ & 7.46 & -130 & 25 & 62 & 34.1 & $\begin{array}{l}\text { From a soft but relatively undisturbed nannofossil- } \\
\text { foraminiferal chalk ooze. }\end{array}$ \\
\hline 64.0 & 4 & 5 & $120-130$ & 7.49 & -220 & 25 & 62 & 34.1 & $\begin{array}{l}\text { From a firm nannofossil-chalk ooze that was slightly } \\
\text { disturbed. Drilling fluid intrusion unlikely. }\end{array}$ \\
\hline 64.1 & 1 & 6 & $0-7$ & 7.41 & -330 & 25 & & & $\begin{array}{l}\text { From a broken up nannofossil chalk that may have } \\
\text { drilling fluid in it. }\end{array}$ \\
\hline 64.1 & 2 & 5 & $72-150$ & & & & & & $\begin{array}{l}\text { From a hard nannofossil chalk that was broken up during } \\
\text { drilling, so that it probably contains drilling fluid. }\end{array}$ \\
\hline 64.1 & 3 & 5 & $141-150$ & 7.23 & -327 & 25 & 64 & 35.2 & $\begin{array}{l}\text { From a badly deformed area that probably has drilling } \\
\text { fluid in it. The core had hard blocks of chalk with soft } \\
\text { disturbed mud. The sample was from the mud. }\end{array}$ \\
\hline
\end{tabular}


TABLE 1 - Continued

\begin{tabular}{|c|c|c|c|c|c|c|c|c|c|}
\hline Hole & Core & Section & $\begin{array}{l}\text { Interval From } \\
\text { Top }(\mathrm{cm})\end{array}$ & $p \mathrm{H}$ & Eh & $\underset{{ }^{\circ} \mathrm{C}}{\mathrm{Temp}}$ & $\Delta \mathrm{N}$ & Salinity & Comments \\
\hline 65.0 & 7 & 6 & $0-10$ & 7.52 & -309 & 25 & 62 & 34.1 & $\begin{array}{l}\text { From a soft disturbed radiolarian ooze that showed little } \\
\text { sign of drilling fluid. }\end{array}$ \\
\hline 65.0 & 9 & 2 & $\begin{array}{c}25-45 \\
75-92 \\
105-150\end{array}$ & & & & & & From a firm radiolarian ooze. \\
\hline 65.0 & 9 & 2 & $\begin{array}{c}25-45 \\
75-95 \\
105-150\end{array}$ & & & & & & $\begin{array}{l}\text { From a disturbed radiolarian ooze that probably does } \\
\text { not have drilling fluid in it. }\end{array}$ \\
\hline 65.0 & 9 & 6 & $90-150$ & & & & & & $\begin{array}{l}\text { From a firm radiolarian ooze which probably does not } \\
\text { contain drilling fluid. }\end{array}$ \\
\hline 65.0 & 9 & 6 & $0-10$ & 7.70 & -362 & 24.1 & 62.5 & 34.4 & $\begin{array}{l}\text { From a soft radiolarian ooze that may have drilling fluid } \\
\text { in it. }\end{array}$ \\
\hline 65.0 & 11 & 5 & $0-11$ & 7.68 & -350 & 24 & 63 & 34.7 & $\begin{array}{l}\text { From a disturbed radiolarian ooze that probably has } \\
\text { some drilling fluid in it. }\end{array}$ \\
\hline 65.0 & 13 & 6 & $0-11$ & 7.63 & -513 & 25 & 62 & 34.1 & $\begin{array}{l}\text { From a radiolarian ooze that was disturbed, so it may } \\
\text { contain drilling fluid. }\end{array}$ \\
\hline 65.0 & 16 & 5 & $140-150$ & 7.69 & -321 & 25 & 62.5 & 34.1 & $\begin{array}{l}\text { From a deformed radiolarian ooze that may contain } \\
\text { drilling fluid. }\end{array}$ \\
\hline 65.1 & 4 & 5 & $0-10$ & 7.69 & -333 & 25 & 62.5 & 34.4 & $\begin{array}{l}\text { From a deformed radiolarian ooze that may contain } \\
\text { drilling fluid. }\end{array}$ \\
\hline 66.0 & 2 & 2 & $139-150$ & 7.65 & -185 & 21.5 & 63 & 34.7 & From a radiolarian ooze with some calcareous bedding. \\
\hline 66.0 & 3 & 5 & $139-150$ & 7.53 & -300 & 21.6 & 63 & 34.7 & $\begin{array}{l}\text { From an olive brown radiolarian ooze which may con- } \\
\text { tain drill fluid. }\end{array}$ \\
\hline 66.0 & 6 & 2 & $66-150$ & & & & & & From a fine-grained brown pelagic clay. \\
\hline 66.0 & 6 & 3 & 150 & 7.79 & +194 & 23 & 62.5 & 34.4 & $\begin{array}{l}\text { From a stiff fine-grained pelagic clay. Probably no drill } \\
\text { fluid. }\end{array}$ \\
\hline 66.0 & 7 & 3 & $139-150$ & & & 24.1 & & & From a grayish-brown pelagic clay. \\
\hline 66.0 & 7 & 4 & $65-150$ & & & & & & From a grayish-brown pelagic clay. \\
\hline 66.0 & 9 & 3 & & 7.66 & -282 & 22 & 63 & 34.7 & From a dark volcanic mud. \\
\hline 66.1 & 2 & 4 & & 7.58 & -380 & 22.2 & 62.5 & 34.4 & $\begin{array}{l}\text { From a radiolarian ooze which probably does not con- } \\
\text { tain drill fluid. }\end{array}$ \\
\hline
\end{tabular}


TABLE 1 - Continued

\begin{tabular}{|c|c|c|c|c|c|c|c|c|c|}
\hline Hole & Core & Section & $\begin{array}{l}\text { Interval From } \\
\text { Top }(\mathrm{cm})\end{array}$ & $p \mathrm{H}$ & Eh & $\underset{{ }^{\circ} \mathrm{C}}{\text { Temp }}$ & $\Delta \mathrm{N}$ & Salinity & Comments \\
\hline 66.1 & 6 & 5 & $0-10$ & 7.59 & 279 & 23.2 & 64 & 35.2 & From a radiolarian ooze which may contain drill fluid. \\
\hline 66.1 & 7 & 3 & $0-70$ & & & & & & From a firm, relatively undisturbed radiolarian ooze. \\
\hline
\end{tabular}

